\title{
Does the nissen fundoplication procedure improve esophageal dysmotility in patients with barrett's esophagus?
}

\section{A fundoplicatura a nissen melhora a dismotilidade esofágica em pacientes com esôfago de barrett?}

Angela M. Falcão 1,2 (1D; Ary Nasi ${ }^{1}$; Sérgio Szachnowicz ${ }^{1}$; Fernando Santa-Cruz ${ }^{3}$; Francisco C. B. C. Seguro ${ }^{1}$; Brena F. Sena ${ }^{4}$; André Duarte'; Rubens A. Sallum, TCBC-SP'; Ivan Cecconello, ECBC-SP'1.

\section{A B S T R A C T}

\begin{abstract}
Objective: to evaluate esophageal dysmotility (ED) and the extent of Barrett's esophagus (BE) before and after laparoscopic Nissen fundoplication (LNF) in patients previously diagnosed with BE and ED. Methods: twenty-two patients with BE diagnosed by upper gastrointestinal ( $\mathrm{Gl}$ ) endoscopy with biopsies and ED diagnosed by conventional esophageal manometry (CEM) were submitted to a LNF, and followed up with clinical evaluations, upper GI endoscopy with biopsies and CEM, for a minimum of 12 months after the surgical procedure. Results: sixteen patients were male (72.7\%) and six were females (27.3\%). The mean age was 55.14 ( \pm 15.52 ) years old. and the mean postoperative follow-up was 26.2 months. The upper Gl endoscopy showed that the mean length of BE was $4.09 \mathrm{~cm}$ preoperatively and $3.91 \mathrm{~cm}$ postoperatively $(\mathrm{p}=0.042)$. The evaluation of esophageal dysmotility through conventional manometry showed that: the preoperative median of the lower esophageal sphincter resting pressure (LESRP) was $9.15 \mathrm{mmHg}$ and 13.2 mmHg postoperatively $(p=0.006)$. The preoperative median of the esophageal contraction amplitude was $47.85 \mathrm{mmHg}$, and $57.50 \mathrm{mmHg}$ postoperatively $(p=0.408)$. Preoperative evaluation of esophageal peristalsis showed that $13.6 \%$ of the sample presented diffuse esophageal spasm and $9.1 \%$ ineffective esophageal motility. In the postoperative, $4.5 \%$ of patients had diffuse esophageal spasm, $13.6 \%$ of aperistalsis and $22.7 \%$ of ineffective motor activity $(p=0.133)$. Conclusion: LNF decreased the BE extension, increased the LES resting pressure, and increased the amplitude of the distal esophageal contraction; however, it was unable to improve ED.
\end{abstract}

Keywords: Esophageal Dysmotility. Barrett's esophagus. Esophageal Manometry. Nissen fundoplication. Esophageal benign diseases.

\section{INTRODUCTION}

Esophageal dysmotility (ED) is a motor disorder to be sought and well evaluated before performing anti-reflux surgery'. ED can be found in patients with gastro-esophageal reflux disease (GERD) 2,3 and Barrett's esophagus $(B E)^{4-6}$.

Increasing evidence indicates that there may be a direct impact of reflux on the inhibitory and excitatory intramural neurons that regulate both peristaltic function and the strength of the esophageal contraction amplitude ${ }^{7-9}$.

The most frequent esophageal motility disorders found in BE and GERD patients are lower esophageal sphincter (LES) hypotonia, ineffective esophageal motility (IEM), diffuse esophageal spasm (DES), esophageal body (EB) hypomotility and aperistalsis ${ }^{3-5}$. However, BE can also be a consequence of an already manifested $E D$, with an increase in the reflux of acid and bile salt content into the esophagus when there are impairments in the esophageal clearance, thus contributing to the development of $\mathrm{BE}^{10-12}$, in a vicious cycle of inflammation and impaired motility leading to a more severe disease ${ }^{13}$.

$\mathrm{BE}$ is described as the presence of a extension of salmon-colored mucosa into the tubular esophagus that extends $\geq 1 \mathrm{~cm}$ proximal to the gastroesophageal junction (GEJ) via an upper gastrointestinal (GI) endoscopy, and histopathological examination shows columnar metaplastic epithelium, containing intestinal goblet cells (intestinal metaplasia) ${ }^{14-16}$. Despite there being only a few symptoms referred, most patients with BE initially complain of having only symptoms associated with persistent GERD, such as regurgitation and heartburn ${ }^{17}$. When the GERD symptoms are associated with dysphagia, or prior to an anti-reflux surgery, an esophageal manometry (EM) examination is a requirement for proper identification and diagnosis 18,19 .

1 - Universidade de São Paulo, Faculdade de Medicina, Departamento de Gastroenterologia, São Paulo - SP - Brasil 2 - Universidade Federal de Pernambuco, Faculdade de Medicina, Departamento de Cirurgia, Recife - PE - Brasil 3 - Universidade Federal de Pernambuco, Faculdade de Medicina, Recife - PE - Brasil 4 - Departamento de Epidemiologia, Escola de Saúde Pública T.H. Chan de Harvard, Boston - MA - EUA 
Laparoscopic Nissen fundoplication (LNF) has been proposed for patients with GERD and BE as an effective and safe therapeutic alternative, especially in cases where inadequate control of reflux symptoms is found during clinical treatment ${ }^{20-22}$. Although this may be true, there is still insufficient data related to the changes in esophageal motility and its evolution after surgical treatment of GERD and BE ${ }^{23-25}$. However, when successful, LNF provides less exposure to acid and bile salt content, reducing esophageal erosion and, consequently, diminished the metaplastic process present in $\mathrm{BE}^{26,27}$.

The aim of the present study is to evaluate esophageal dysmotility and the extent of BE before and after LNF in patients previously diagnosed with BE and ED.

\section{MATERIALS AND METHODS}

\section{Study design}

This study was carried out at the Clinics Hospital at the University of São Paulo Medical School (HC-FMUSP), in São Paulo, SP, Brazil. Participants were identified at the Barrett's esophagus outpatient clinic in the period between January 2010 and January 2015. All procedures performed were in accordance with the ethical standards of the institutional research committee of the institution and, with the 1964 Helsinki declaration and its later amendments or comparable ethical standards. This research project was approved by the Ethics Committee for Research of the FMUSP (N0.2.399.947) CAAE:77125917.8.0000.0068.

Twenty-two individuals with symptoms of heartburn and regurgitation, diagnosed with $\mathrm{BE}$ via upper $\mathrm{Gl}$ endoscopy and confirmed by the presence of a metaplastic columnar epithelium, containing goblet cells (intestinal metaplasia) at histopathological examination, with esophageal dysmotility via conventional esophageal manometry (CEM) and who also underwent a LNF, were included in the study. The extent of Barrett's epithelium, in centimeters, was assessed before and after surgery. Patients who presented recurrence of reflux symptoms or fundoplication complications, such as twisted or slipped valve, identified in a postoperative upper Gl endoscopy were excluded from the study. Preoperative and postoperative CEM studies were performed by two of the study researchers not involved in the clinical management of the patients. At the time of the postoperative manometric assessment, the patients had at least 12 months of follow-up after surgery in order to determine the real impact of the LNF on their ED. All patients underwent a 24-hour $\mathrm{pH}$-metry test to evaluate the effective control of reflux, in the postoperative follow-up of NLF. They were considered normal by the DeMeester score below 14.74.

\section{Manometry study}

The esophageal manometry measurements were performed using a CEM device with a polyvinyl catheter of $75 \mathrm{~cm}$ of length and $45 \mathrm{~mm}$ of diameter, with 8 capillary channels. The catheter was perfused with water at a flow rate of $0.6 \mathrm{~mL} / \mathrm{min} / \mathrm{channel}$ through a pneumohydraulic perfusion system of low complacency.

Esophageal manometry assessed LES resting pressure (LESRP), esophageal peristaltic function and esophageal contraction.

The ED alterations evaluated were: LES hypotonia, diffuse esophageal spasm (DES), ineffective esophageal motility (IEM), distal esophageal body (EB) aperistalsis, distal EB hyper and hypocontractility.

Diffuse esophageal spasm (DES) was defined as simultaneous contractions in the esophageal body in $20 \%$ or more of wet swallows; ineffective esophageal motility (IEM) was defined as having $30 \%$ of contractions in the distal esophagus with low amplitude $(<30 \mathrm{mmHg})$ and/ or having $30 \%$ of contractions that are not transmitted; aperistalsis was defined when $100 \%$ of wet swallows are followed by simultaneous esophageal contractions; esophageal body (EB) hypocontractility was defined as an EB pressure below $64 \mathrm{mmHg}$, EB hypercontractility was defined as an EB pressure above $180 \mathrm{mmHg}$. LES hypotonia was defined as LESRP below $14 \mathrm{mmHg}^{28-30}$. The LES baseline tone was assessed using the mean airway resting pressure ${ }^{28}$.

Conventional esophageal manometry (CEM) was used instead of a high-resolution manometry (HRM) due to the fact that, in the preoperative evaluation, the Digestive Surgery Division did not have yet a highresolution manometry device. 


\section{Statistical analysis}

Data analysis included an initial descriptive exploration of the data including mean, standard deviation, median, 25th and 75th percentile of the quantitative variables and proportion with a 95\% confidence interval $(95 \% \mathrm{Cl})$ for the qualitative ones. The Fisher exact test and Pearson Chi-Square tests were used for association analysis in the contingency table. The Shapiro-Wilk Normality Test was used to evaluate quantitative variables in a normal distribution. The paired Wilcoxon test and paired Student's t-test was used to compare if the preoperative position measurements were the same as the postoperative, considering the dependence found between the times. All the tests performed took into consideration a bidirectional of 0.05 and a $95 \%$ confidence interval $(\mathrm{Cl})$ and were performed with computational support of the software Stata 12.0 for Windows and Excel 2010 (Microsoft Office).

\section{RESULTS}

All patients included had no reflux or dysphagia symptoms in the first 12 months of follow-up, without the use of proton pump inhibitors (PPI). Overall, sixteen patients were male $(72.7 \%)$ and six females (27.3\%). The mean participant age was $55.14( \pm 15.52)$ years preoperatively and 58.81 ( \pm 13.79 ) postoperatively. The mean postoperative follow-up time was of 26,2 ( \pm $9,27)$ months. Reduction or absence of acid reflux was observed in all patients evaluated at 24-hour pH-metry after anti-reflux surgery with a mean DeMeester score of $2.45( \pm 3.32)$, and no deaths occurred during the study period.

A decreased length of columnar mucosa was observed in the upper Gl endoscopy, from 4.09 $\mathrm{cm}( \pm 2.50)$ preoperatively to $3.91 \mathrm{~cm}( \pm 2.34)$ in the postoperative evaluation $(p=0.042)$.

In the CEM, the analysis of the LES resting pressure showed increase in its median (25th; 75th) values, going from $9.15(5.78 ; 11.93) \mathrm{mmHg}$ in the preoperative evaluation to $13.2(11.0 ; 16.28) \mathrm{mmHg}$ in the postoperative evaluation $(p=0.013)$. Besides, percentage of LES hypotonia decreased from $86.3 \%$ to $54.5 \%$ after LNF $(p=0.021)$.

The median (25th; 75th) values of the distal esophageal body pressure (EBP) increased from 47.85 $(35.65 ; 60.43) \mathrm{mmHg}$ in the preoperative stage to 57.50 $(34.10 ; 80.45) \mathrm{mmHg}$ in the postoperative evaluation $(p=0.408)$ (Table 1).

Table 1. Length of the Barrett's esophagus and manometry findings for lower esophageal sphincter resting pressure and esophageal body pressure.

\begin{tabular}{|c|c|c|c|}
\hline & \multicolumn{2}{|c|}{ Evaluation } & p-value \\
\hline \multirow{2}{*}{ Variables } & Preoperative & Postoperative & \\
\hline & Mean \pm SD & Mean \pm SD & \\
\hline \multirow[t]{2}{*}{ BE lenght $(\mathrm{cm})$} & $4.09 \pm 2.50$ & $3.91 \pm 2.34$ & 0.042 * \\
\hline & Preoperative & Postoperative & \\
\hline \multirow[t]{2}{*}{ LESRP } & Median (25th; 75th) & Median (25th; 75th) & 0.006 ** \\
\hline & $9.15(5.78 ; 11.93)$ & $13.20(11.00 ; 16.28)$ & \\
\hline \multirow{2}{*}{ LES hypotonia } & Preoperative N (\%) & Postoperative N (\%) & $0071,(x+1)$ \\
\hline & $19(86.3)$ & $12(54.5)$ & $0.0 \angle 1(\wedge n)$ \\
\hline \multirow{3}{*}{ EBP } & Preoperative & Postoperative & \\
\hline & Median (25th; 75th) & Median (25th; 75th) & $0.408 * *$ \\
\hline & $47.85(35.65 ; 60.43)$ & $57.50(34.10 ; 80.45)$ & \\
\hline
\end{tabular}

BE: Barrett's esophagus; LESRP: lower esophageal sphincter resting pressure; EBP: esophageal body pressure; $\left({ }^{*}\right)$ Paired t-Student test; $\left({ }^{* *}\right)$ Wilcoxon test. $(* * *)$ Pearson Qui-Square test. 
When we analyzed the presence of ED, preoperative evaluation showed that $13.6 \%$ of the samples presented diffuse esophageal spasm (DES) and $9.1 \%$ ineffective esophageal motility (IEM). In the postoperative phase, $4.5 \%$ of the patients displayed DES, $22.7 \%$ showed IEM and $13.6 \%$ aperistalsis. There was no significant difference between the preoperative and postoperative evaluation either together $(p=0.195)$ or when analyzing each ED separately $(p=0.133)$ (Table 2$)$.

Table 2. Esophageal dysmotility disorders at the pre and postoperative evaluations.

\begin{tabular}{lccc}
\hline & \multicolumn{2}{c}{ Evaluation } & p-value \\
\hline Variables & $\begin{array}{c}\text { Preoperative } \\
\mathrm{n}(\%)\end{array}$ & $\begin{array}{c}\text { Postoperative } \\
\mathrm{n}(\%)\end{array}$ & \\
\hline ED & $5(22.7)$ & $9(40.9)$ & $0.195 * \star$ \\
\hline DES & $3(13.6)$ & $1(4.5)$ & \\
Aperistalsis & $0(0.0)$ & $3(13.6)$ & 0.133 * \\
IEM & $2(9.1)$ & $5(22.7)$ & \\
\hline
\end{tabular}

$(* \star)$ Pearson Qui-Square test.

\section{DISCUSSION}

It is common knowledge that a clinically successful fundoplication is capable of providing satisfactory control of duodenal-gastro-esophageal reflux ${ }^{26}$. However, the timing for indication of this surgical procedure, for patients with $B E$ and $E D$, is still a challenge ${ }^{31}$.

In our study, we observed a reduction in $\mathrm{BE}$ length, from $4.09 \mathrm{~cm}( \pm 2.50)$ preoperatively to $3.91 \mathrm{~cm}$ $( \pm 2.34)$ postoperatively $(p=0.042)$. Other authors have also reported a regression of the esophageal intestinal metaplasia after fundoplication ${ }^{32-35}$.

Our data showed that patients with preoperative esophageal hypercontractility evolved with normal postoperative esophageal contraction pressure. These data are similar to those described by Barreca et al. ${ }^{36}$, who observed a return to normal manometric patterns in $80 \%$ of patients after successful control of esophageal acid exposure. These authors further describe that high esophageal contractions may be associated with GERD and a Nissen fundoplication can effectively control GERD and should not be contraindicated.

In addition, our data also showed a tendency to improve esophageal body contraction amplitude, with increases in esophageal body pressure (EBP). The median values (25th; 75th) of EBP increased from 47.85 (35.65; $60.43) \mathrm{mmHg}$ preoperatively to $57.50(34.10 ; 80.45)$ $\mathrm{mmHg}$ in the evaluation postoperatively $(p=0.408)$.

When we analyzed the occurrence of $E D$, our preoperative evaluation showed that $13.6 \%$ of the samples presented DES and $9.1 \%$ ineffective esophageal motility (IEM), and postoperatively, $4.5 \%$ of patients had DES, $22.7 \%$ had IEM and $13.6 \%$ had aperistalsis; without a significant difference between the preoperative and postoperative evaluation either together ( $p=0.195)$ or when analyzing each ED separately $(p=0.133)$.

Our results corroborate the findings of Fibbe et al., where the authors found an increased LESRP in the postoperative period of anti-reflux surgery. In addition, they showed that esophageal contraction amplitude and primary peristalsis did not return to normal after fundoplication ${ }^{37}$. Notwithstanding, only a small part of their sample was composed of patients with BE.

Fuchs et al. on the other hand, showed that after Nissen's fundoplication, esophageal motility normalized, especially in patients with preoperative hypomotility, and concluded that patients with impaired esophageal motility should not be excluded from anti-reflux surgery per $\mathrm{se}^{38}$.

Furthermore, the present study also demonstrated that for follow-up periods longer than 12 months, patients undergoing successful fundoplication had an increase in LESRP with median values (25th; 75th) from $9.15(5.78 ; 11.93) \mathrm{mmHg}$ in the preoperative evaluation to $13.2(11.0 ; 16.28) \mathrm{mmHg}$ postoperatively $(p=0.013)$, where none of the patients complained of dysphagia. On the other hand, another study indicated an increased risk of dysphagia symptoms after Nissen fundoplication for patients with esophageal motility disorders ${ }^{39}$

Moreover, Riedl et al., described that anti-reflux surgery is effective in the treatment of GERD, regardless of the preoperative manometric findings ${ }^{40}$ and they also concluded that this type of surgery does not worsen the symptoms of preoperative dysphagia, as reported by other authors ${ }^{41}$. However, Wilshire et al. showed that after Nissen fundoplication, dysphagia is linked to an abnormal hiatal functional anatomy, i.e. impaired relaxation of the high-pressure zone rather than motility changes ${ }^{42}$. 
Similarly, Yamamoto et al. retrospectively observed that the vast majority of patients with postoperative dysphagia had evidence of hiatal flow obstruction, which was linked to longer lengths of the high-pressure zone and higher relaxation pressures, rather than motor disorders of the esophageal body ${ }^{43}$.

Gill et al. also evaluated esophageal motility through a manometric study before and after fundoplication ${ }^{44}$. They found that, despite satisfactory GERD symptoms relief and increased LES and EB pressure, Nissen fundoplication led to an increase in aperistalsis episodes. These findings are in accordance with ours results, still it is difficult to establish a reliable comparison, because, unlike our study, Gill et al. did not evaluate patients with $\mathrm{BE}$.

The "tailored" approach in patients with GERD who are candidates for surgery has not been suggested either especially for those in which preoperative manometry demonstrates ineffective peristalsis, in line with the available evidence that the outcome of antireflux surgery in patients with esophageal dysmotility is not affected by a total fundoplication approach ${ }^{45-47}$. In addition, a higher incidence of recurrent reflux has been reported after Toupet or Lind fundoplication ${ }^{48,49}$.

The importance of studying possible interventions that may affect ED is based on the fact that impaired motility compromises the esophageal clearance, increasing the exposure of the distal esophageal mucosa to acid and bile salts reflux content and, thus, accelerating the process of intestinal metaplasia observed in $\mathrm{BE}^{5,50}$.
It is expected that a clinically successful fundoplication would lead to an increased LESRP due to the anti-reflux mechanism of this surgery. However, the main endpoints here are the effects of this procedure on the impaired EB contraction. Although we found a tendency for improvement in esophageal contraction with increased esophageal body amplitude after laparoscopic Nissen fundoplication, we also observed that the prevalence of ED, such as DES, IME and aperistalsis, increased after surgery.

We are aware that the main limitations of the current study are in the small number of patients evaluated and in the use of conventional manometry procedures instead of high-resolution manometry (HRM) to assess esophageal dysmotility. However, even with such limitations, we believe the current study presents important results regarding the long-term effects of Nissen fundoplication in patients with BE and ED.

\section{CONCLUSION}

In conclusion, LNF decreased the BE extension, increased the LES resting pressure, and increased the amplitude of the distal esophageal contraction; however, it was unable to improve ED.

In order to establish more solid conclusions regarding the real impact of the LNF on ED in patients with $\mathrm{BE}$, it is of paramount importance that new studies are developed with a larger sample and longer follow-up period.

\section{R E S U M O}

Objetivo: avaliar a dismotilidade esofágica (DE) e a extensão do esôfago de Barrett (EB) antes e depois da fundoplicatura laparoscópica a Nissen (FLN) em pacientes previamente diagnosticados Com EB e DE. Método: vinte e dois pacientes com EB diagnosticada por endoscopia digestiva alta (EDA) com biópsias e DE diagnosticada por manometria esofágica convencional (MEC) foram submetidos a FLN, e acompanhados por avaliações clínicas, endoscopia digestiva alta com biópsias e MEC, por no mínimo 12 meses após o procedimento cirúrgico. Resultados: dezesseis pacientes eram do sexo masculino (72,7\%) e seis do feminino (27,3\%). A média de idade foi de 55,14 ( $\pm 15,52)$ anos e o seguimento pós-operatório médio foi de 26,2 meses. A endoscopia digestiva alta mostrou que o comprimento médio do $E B$ foi de $4,09 \mathrm{~cm}$ no pré-operatório e 3,91 cm no pós-operatório $(p=0,042)$. $A$ avaliação da dismotilidade esofágica por meio da manometria convencional mostrou que a mediana pré-operatória da pressão de repouso do esfíncter esofágico inferior (PREEI) foi de $9,15 \mathrm{mmHg}$, e de 13,2 mmHg no pós-operatório $(p=0,006)$. A mediana pré-operatória da amplitude de contração esofágica foi de $47,85 \mathrm{mmHg}$, e de $57,50 \mathrm{mmHg}$ no pós-operatório $(p=0,408)$. A avaliação pré-operatória do peristaltismo esofágico mostrou que $13,6 \%$ da amostra apresentava espasmo esofágico difuso e 9,1\%, motilidade esofágica ineficaz. No pós-operatório, 4,5\% dos pacientes apresentaram espasmo esofágico difuso, 13,6\% de aperistalse e 22,7\% de atividade motora ineficaz $(p=0,133)$. Conclusões: a FLN diminuiu a extensão do $E B$, aumentou a pressão de repouso do EEI e aumentou a amplitude da contração esofágica distal; no entanto, não foi capaz de melhorar a DE.

Palavras chave: Dismotilidade Esofágica. Esôfago de Barrett. Manometria Esofágica. Fundoplicatura de Nissen. Doenças Benignas do Esôfago. 


\section{REFERENCES}

1. Gockel I. Rabe SM, Niebisch S. Before and after Esophageal Surgery: Which Information is Needed from the Functional Laboratory. Review Article. Visc Med 2018; 34:116-121.

2. Martinucci I, de Bortoli N, Giacchino M, Bodini G, Marabotto E, Marchi S, et al. Esophageal motility abnormalities in gastroesophageal reflux disease. World J Gastrointest Pharmacol Ther, 2014 May 6; 5(2): 86-96.

3. Falcão A, Nasi A, Brandão J, Sallum R, Cecconello I. What is the real impairment on esophageal motility in patients with gastroesophageal reflux disease? Arq. Gastroenterol. 2013;50(2):111-116.

4. Ang D, Blondeau K, Sifrim D, Tack J. The spectrum of motor function abnormalities in gastroesophageal reflux disease and Barrett's esophagus. Digestion. 2009; 79:158-68.

5. Bazin C, Benezech A, Alessandrini M, Grimaud JC, Vitton V. Esophageal Motor Disorders Are a Strong and Independant Associated Factor of Barrett's Esophagus. J Neurogastroenterol Motil. 2018; 24(2):216-225.

6. Menezes MA, Herbella FAM. Pathophysiology of Gastroesophageal Reflux Disease. World J Surg. 2017;41(7):1666-1671. doi:10.1007/s00268-0173952-4.

7. Felix VN, Devault K, Penagini R, Elvevi A, Swanstrom $L$, Wassenaar $E$, et al. Causes and treatments of achalasia, and primary disorders of the esophageal body. Ann N Y Acad Sci 2013; 1300:236-249.

8. Gadelha KKL, Batista-Lima FJ, de Oliveira DMN, Carvalho EF, Sifrim D, Santos AAD, et al. Impairment of rat oesophageal muscle contractility associated with experimental non-erosive oesophageal mucosal damage. Exp Physiol. 2019 Feb;104(2):199-208.

9. Chan WW, Haroian LR, Gyawali CP. Value of preoperative esophageal function studies before laparoscopic antireflux surgery. Surg Endosc, 2011; 25:2943-2949.

10. Bhardwaj $V$, Horvat A, Korolkova O, Washington MK, El-Rifai W, Dikalov SI, et al. Prevention of DNA damage in Barrett's esophageal cells exposed to acidic bile salts. Carcinogenesis. 2016 Dec;37(12):1161-
1169.

11. Woodland $P$, Sifrim $D$. The refluxate: The impact of its magnitude, composition and distribution. Best Pract Res Clin Gastroenterol. 2010 Dec;24(6):861-71.

12. Souza RF. The Role of Acid and Bile Reflux in Esophagitis and Barrett's Metaplasia. Biochem Soc Trans. 2010 Apr; 38(2): 348-352.

13. Diamant NE. Pathophysiology of gastroesophageal reflux disease. GI Motility online (2006) doi:10.1038/ gimo21.

14. Eluri S, Shaheen NJ. Barrett's esophagus: diagnosis and management. Gastrointest Endosc. 2017;85(5):889903.

15. Fitzgerald RC, di Pietro $M$, Ragunath $K$, Ang $Y$, Kang JY, Watson P, et al. British Society of Gastroenterology guidelines on the diagnosis and management of Barrett's oesophagus. Gut 2014; 63:7-42.

16. Sanghi $V$ and Thota PN. Barrett's esophagus: novel strategies for screening and surveillance. Ther Adv Chronic Dis 2019, Vol. 10: 1-14.

17. Zagari RM, Fuccio L, Wallander MA, Johansson $S$, Fiocca R, Casanova $S$, et al. Gastroesophageal reflux symptoms, oesophagitis and Barrett's oesophagus in the general population: the Loiano-Monghidoro study. Gut 2008; 57:1354-1359.

18. Zehetner J, Lipham JC: Chapter 8: Preoperative evaluation and testing for GERD; in Swanström LL, Dunst CM (eds): Antireflux Surgery. New York, NY, Springer, 2015, pp 69-78.

19. Teitelbaum EN, Soper NJ: Chapter 9: Laparoscopic Nissen fundoplication; in Swanström LL, Soper NJ (eds): Mastery of Endoscopic and Laparoscopic Surgery, ed 4. Philadelphia, PA, Lippincott Williams \& Wilkins, 2013, pp 101-113.

20. Parise $P$, Rosati R, Savarino E, Locatelli A, Ceolin M, Dua KS, et al. Barrett's esophagus: surgical treatments. Ann. N.Y. Acad. Sci. 1232 (2011) 175-195.

21. Shaheen NJ, Falk GW, lyer PG, Gerson LB. ACG Clinical Guideline: Diagnosis and management of Barrett's esophagus. Am J Gastroenterol, 2016; 111:30-50.

22. Díaz Vico T, Elli EF. Clinical outcomes of gastroesophageal reflux disease-related chronic cough following antireflux fundoplication. Esophagus. 2019; 15:1-7.

23. Richter JE, Rubenstein JH. Presentation and 
epidemiology of gastroesophageal reflux disease. Gastroenterology. 2018;154(2):267-276.

24. Zehetner J, DeMeester SR, Ayazi S, Costales JL, Augustin F, Oezcelik A, et al. Long-term Follow-up After Anti-Reflux Surgery in Patients with Barrett's Esophagus. J Gastrointest Surg (2010) 14:14831491.

25. Armijo PR, Hennings $D$, Leon $M$, Pratap $A$, Wheeler A, Oleynikov D. Surgical Management of Gastroesophageal Reflux Disease in Patients with Severe Esophageal Dysmotility. J Gastrointest Surg. 2019 Jan;23(1):36-42.

26. Herbella FAM, Schlottmann F, Patti MG. Antireflux Surgery and Barrett's Esophagus: Myth or Reality? World J Surg. 2018;42(6):1798-1802.

27. Rossi $M$, Barreca $M$, de Bortoli N, Renzi C, Santi S, Gennai A, Bellini M, Costa F, Conio M, Marchi S. Efficacy of Nissen fundoplication versus medical therapy in the regression of low-grade dysplasia in patients with Barrett esophagus: a prospective study. Ann Surg 2006; 243:58-63.

28. Bremner C, DeMeester TR, Bremner RM, Mason RJ. Esophageal motility testing: Made easy, 2001; chapter 2:13-51.

29. Spechler SJ, Castell DO. Classification of oesophageal motility abnormalities. Gut. 2001; 49:145-51.

30. Savarino E, de Bortoli N, Bellinl M, Galeazzi F, Ribolsi $M$, Salvador $R$, et al. Practice guidelines on the use of esophageal manometry - A GISMAD-SIGE-AIGO medical position statement. Dig Liver Dis. 2016 Oct;48(10):1124-35.

31. Jonnalagadda S. Anti-reflux surgery for Barrett's esophagus? Gastroenterology 2004; 126: 610-611.

32. Knight BC, Devitt PG, Watson DI, Smith LT, Jamieson GG, Thompson SK. Long-term Efficacy of Laparoscopic Antireflux Surgery on Regression of Barrett's Esophagus Using BRAVO Wireless pH Monitoring: A Prospective Clinical Cohort Study. Ann Surg. 2017 Dec;266(6):1000-1005.

33. Mohamed AA, Mahran KM, Zaazou MM. Impact of Laparoscopic Nissen Fundoplication on Noncomplicated Barrett's Esophagus. Saudi J Gastroenterol 2011; 17:185-8.

34. Gurski RR, Peters JH, Hagen JA, DeMeester SR, Bremner CG, Chandrasoma PT, et al. Barrett's esophagus can and does regress after antireflux surgery: A study of prevalence and predictive features. J Am Coll Surg 2003; 196:706-13.

35. Migaczewski M, Pędziwiatr M, Matłok M, Budzyński A. Laparoscopic Nissen fundoplication in the treatment of Barrett's esophagus - 10 years of experience. Wideochir Inne Tech Maloinwazyjne. 2013 Jun;8(2):139-45.

36. Barreca M, Oelschlager BK, Pellegrini CA. Outcomes of laparoscopic Nissen fundoplication in patient with the "Hypercontractile Esophagus". Arch Surg. 2002; 137:724-729.

37. Fibbe C, Layer $\mathbf{P}$, Keller J, Strate U, Emmermann A, Zornig $C$. Esophageal motility in reflux disease before and after fundoplication: a prospective, randomized, clinical, and manometric study. Gastroenterology. 2001; 121:5-14.

38. Fuchs HF, Gutschow CA, Brinkmann S, Herbold T, Bludau M, Schröder W, et al. Effect of Laparoscopic Antireflux Surgery on Esophageal Motility. Dig Surg 2014; 31:354-358.

39. Pizza F, Rossetti G, Del Genio G, Maffettone V, Brusciano L, Del Genio A. Influence of esophageal motility on the outcome of laparoscopic total fundoplication. Dis Esophagus.2008;21:78-85.

40. Riedl O, Gadenstätter M, Lechner W, Schwab G, Marker M, Ciovica R. Preoperative lower esophageal sphincter manometry data neither impact manifestations of GERD nor outcome after laparoscopic Nissen fundoplication. J Gastrointest Surg. 2009; 13:1189-1197.

41. Tian ZC, Wang B, Shan CX, Zhang W, Jiang DZ, Qiu M. A Meta-Analysis of Randomized Controlled Trials to Compare Long-Term Outcomes of Nissen and Toupet Fundoplication for Gastroesophageal Reflux Disease. PLoS One. 2015;10(6): e0127627.

42. Wilshire $C L$, Niebisch $S$, Watson TJ, Litle VR, Peyre $C G$, Jones $C E$, et al. Dysphagia postfundoplication: more commonly hiatal outflow resistance than poor esophageal body motility. Surgery. 2012; 152:584592.

43. Yamamoto SR, Akimoto S, Hoshino M, Mittal SK. High-resolution manometry findings in symptomatic post-Nissen fundoplication patients with normal endoscopic configuration. Dis Esophagus. 
2016;29(8):967-970.

44. Gill RC, Bowes KL, Murphy PD, Kingma YJ. Esophageal motor abnormalities in gastroesophageal reflux and the effects of fundoplication. Gastroenterology 1986; 91:364-369.

45. Oleynikov D, Eubanks TR, Oelschlager BK, Pellegrini CA. Total fundoplication is the operation of choice for patients with gastroesophageal reflux and defective peristalsis. Surg Endosc. 2002; 16:909e913.

46. Booth MI, Stratford J, Jones L, Dehn TC. Randomized clinical trial of laparoscopic total (Nissen) versus posterior partial (Toupet) fundoplication for gastrooesophageal reflux disease based on preoperative oesophageal manometry. Br J Surg. 2008;95:57e63.

47. Chrysos E, Tsiaoussis J, Zoras OJ, Athanasakis E, Mantides A, Katsamouris A, et al. Laparoscopic

Received in: 27/05/2020

Accepted for publication: 20/07/2020

Conflict of interest: no.

Funding source: none. surgery for gastroesophageal reflux disease patients with impaired esophageal peristalsis: Total or partial fundoplication? J Am Coll Surg. 2003;197: 8e15.

48. Csendes A, Orellana O, Cuneo N, Martínez G, Figueroa $M$. Long-term (15-year) objective evaluation of 150 patients after laparoscopic Nissen fundoplication. Surgery. 2019 Jun 18. pii: S0039-6060(19)30205-3.

49. Patti MG, Robinson T, Galvani C, Gorodner MV, Fisichella PM, Way LW. Total fundoplication is superior to partial fundoplication even when esophageal peristalsis is weak. J Am Coll Surg. 2004; 198:863e869. discussion 869e870.

50. Diener U, Patti MG, Molena D, Fisichella PM, Way LW. Esophageal dysmotility and gastroesophageal reflux disease. J Gastrointest Surg Off J Soc Surg Aliment Tract. 2001; 5:260-265.

\section{Mailing address:}

Angela M Falcão

E-mail: angela.figueiredofalcao@ufpe.br

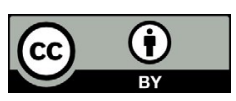

